\title{
Systematic method of risk assessment in industrial processes
}

\author{
K. Zánická Hollá, J. Ristvej \& L. Šimák \\ Department of Crisis Management, University of Žilina, Slovakia
}

\begin{abstract}
Mankind has passed over a significant historical frontier, namely the expansion of technological processes where hazardous substances are potential threats for employees, the public, the environment and property and, therefore, it is there is an inevitable need to pay increased attention to the occurrence of industrial accidents and, mainly, their prevention. The area of safety of technical and technological systems is very closely connected, not only with the reliability of the processes but it has also wider linkages with regard to the technical, social, legal and other aspects. There exist several systematic approaches, methods and techniques to assess industrial processes and risks linked to these processes on the European Union level and also on the national level of each member state. We can mention some basic systematic approaches - MOSAR, CPQRA, ARAMIS, PRA (PSA) widely used in this area. However, according to analyst's needs, they usually miss the structured and systematic approach of how to complete the risk assessment in steps and what the content of each of these steps is. The main focus of this paper is to discuss the theoretical aspects of risk assessment in industrial processes and to show the possible approach of a structured and systematic method with support of logical diagrams to fulfil all tasks concerning the industrial accident assessment. Last but not least we present the research activities of the Department of Crisis Management, University of Žilina in Žilina, Slovakia.
\end{abstract}

Keywords: risk assessment, industrial processes, industrial accident assessment.

\section{Introduction}

We have passed over the significant historical frontier and entered the third millennium which has been given many attributes by the prominent personalities of our era. We are speaking about the information society, however, on the other 
hand about the period of global climatic changes and natural catastrophes, as well as industrial accidents, and about the time period when it is inevitable to bear in mind also social risks and their impacts on society. We had a century that brought people the largest development and progress but also huge suffering, poverty and hunger. Wars, national turbulences and religious discrepancies, increasing unemployment rates, terrorism, organised crime, ecological catastrophes, industrial accidents, elements with their enormous devastating effects, all of that were the negative phenomena slowing down the development of human society.

Nowadays, every manufacturing enterprise, company providing services or transport wants to be successful. Its goal is to secure the prosperity of the business and to achieve it through manufacturing or services. The technological processes and equipment are closely linked with the industrial risks, which have become the object of assessing their decrease to an acceptable level, and last but not least permanent monitoring of the risks from the point of view of enterprises, as well as selected bodies of the public administration. Perception and awareness of the need to prevent increasing the crisis phenomena is for the society, as well as legal entities or the people of society, who are very important. Overlooking and insufficient attention paid to the risks could have negative impacts for all

Table 1: $\quad$ Reports about the rise of emergencies - section of Civil Defence and Crisis Management of the Ministry of Interior of the Slovak Republic in 2009.

\begin{tabular}{|c|c|}
\hline Emergency & Quantity \\
\hline Natural disasters & \\
\hline spates and floods & 20 \\
\hline consequences of windstorm & 4 \\
\hline calamitous snowfalls and avalanches & 13 \\
\hline Landslides & 6 \\
\hline Accidents & \\
\hline leakages of dangerous substances & 20 \\
\hline fires and explosions & 20 \\
\hline damaging distribution networks & 1 \\
\hline Catastrophes & \\
\hline big car accident & 1 \\
\hline Others & \\
\hline suspicious parcels and finding dangerous substances & 16 \\
\hline car accidents & 3 \\
\hline Scaremongering & 4 \\
\hline slide of part of family house & 1 \\
\hline outbreak of gnats & 1 \\
\hline attacking people by tear gas & 1 \\
\hline
\end{tabular}




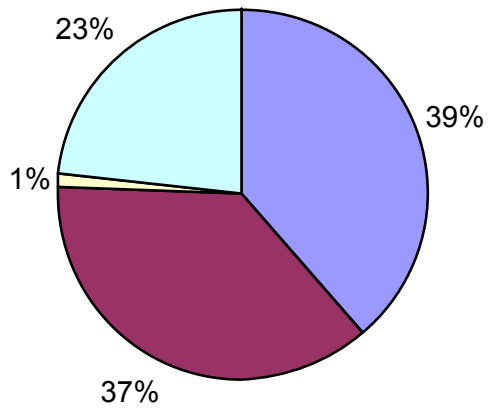

口 Natural Disasters

$\square$ Accidents

$\square$ Catastrophes

$\square$ Others

Figure 1: Proportion of received announcements about emergencies by the section of Civil Defence and Crisis Management of the Ministry of Interior of the Slovak Republic in 2009.

people. An important part of the risk assessment process is also inspecting and monitoring the adopted measures in connection with the effort to decrease their number.

In 2009, 111 emergency announcements were received by the Section of Civil Defence and Crisis Management of the Ministry of Interior of the Slovak Republic in Slovakia, which is the contact place for receiving and providing information about emergencies. Compared with 2008 there were 15 more events of this kind, which is an increase by $13.5 \%$. Figure 1 depicts the proportion of the basic types of emergencies in 2009.

Compared with previous years there was increase in the number of natural disasters and accidents, which (as follows from the figure No. 1) represent also the largest proportion among the emergencies in 2009. From the point of view of the accidents and natural disasters their number is comparable, although this opinion is often suppressed. It is said that the number of the natural disasters is in general higher. Industrial accidents, which represent one of the biggest threats in the current society, are the topic of this article and it is necessary to create methods for their suppression.

The area of the safety of technical and technological systems is very closely connected, not only with the reliability of the processes but it has also wider linkages regarding technical, social, legal and other aspects. The legal aspects of safety are in practice neglected very frequently in spite of the fact that they can be of principal importance. Prevention of the rise of industrial accidents is substantially dependent on the technical solution of the machine or technological equipment, with the properties of hazardous substances utilised in the processes, however, they are also linked with unambiguous keeping of the principles stated by the relevant legal standards and methods created. 
The necessity of reliability and safety belongs among the basic requirements that form the conditions for continual fulfilment of the working tasks and providing services. People are part of the safety in the position of the cognising and performing subjects. Without human beings and human society there would be no safety. The safety of the machines and technical equipment, as well as industrial processes, has in general the character of the subject-object relationship in the framework of which we recognise its objective and subjective aspect:

- The objective aspect of the machines' and technical equipment's safety condition is based on the fact that:

- $\quad$ No evidence of the existence of danger that threatens the characteristic safety features of the object or system (there is no real possibility of an accident, restriction of the functionality of the object or system assessed, or violating its existence),

- $\quad$ There is sufficient amount of resources and technical solutions for minimising the danger in the designed machines or technical equipment.

- The subjective aspect of the machines', equipment's and industrial processes' safety in general. It is based on the fact that the responsible designer or user of the machine or technology is not aware of the danger. $\mathrm{He} / \mathrm{she}$ feels safe because:

- He/she does not have enough information about the dangerous properties of the machine or technological equipment,

$\mathrm{He} / \mathrm{she}$ is not able to perceive and evaluate the danger related to the operation of the machine or technological equipment objectively,

- $\quad$ The subject concerned is able to decrease the actual risks connected with the operation of the machine or technological equipment efficiently and to create effective protection against threats due to the possible accident (Šimák [13]).

It is essential to understand, assess and present externally the safety of the machines, technical equipment and industrial processes as a whole and as a complex, widely structured and multidimensional phenomenon that is linked with the rate of protection of life, employees' and inhabitants' health, the property of the society, of the legal entities and citizens, as well as the environment. The structural character and hierarchisation of the safety of the machines and technical equipment reflects in a wider vertical (is derived from the complexity of the system, the level of its control, sub-suppliers, or customers), as well as horizontal structure, of the safety.

Instability is the source of the overall imbalance of the technical or technological system and in this way the violation of the operational status and the occurrence of a subsequent accident, or an emergency. The rate of instability is a deviation from the real target result, performance or effect from the assumed (planned) result. Figure 2 offers a graphical depiction of the progress of human activities. 


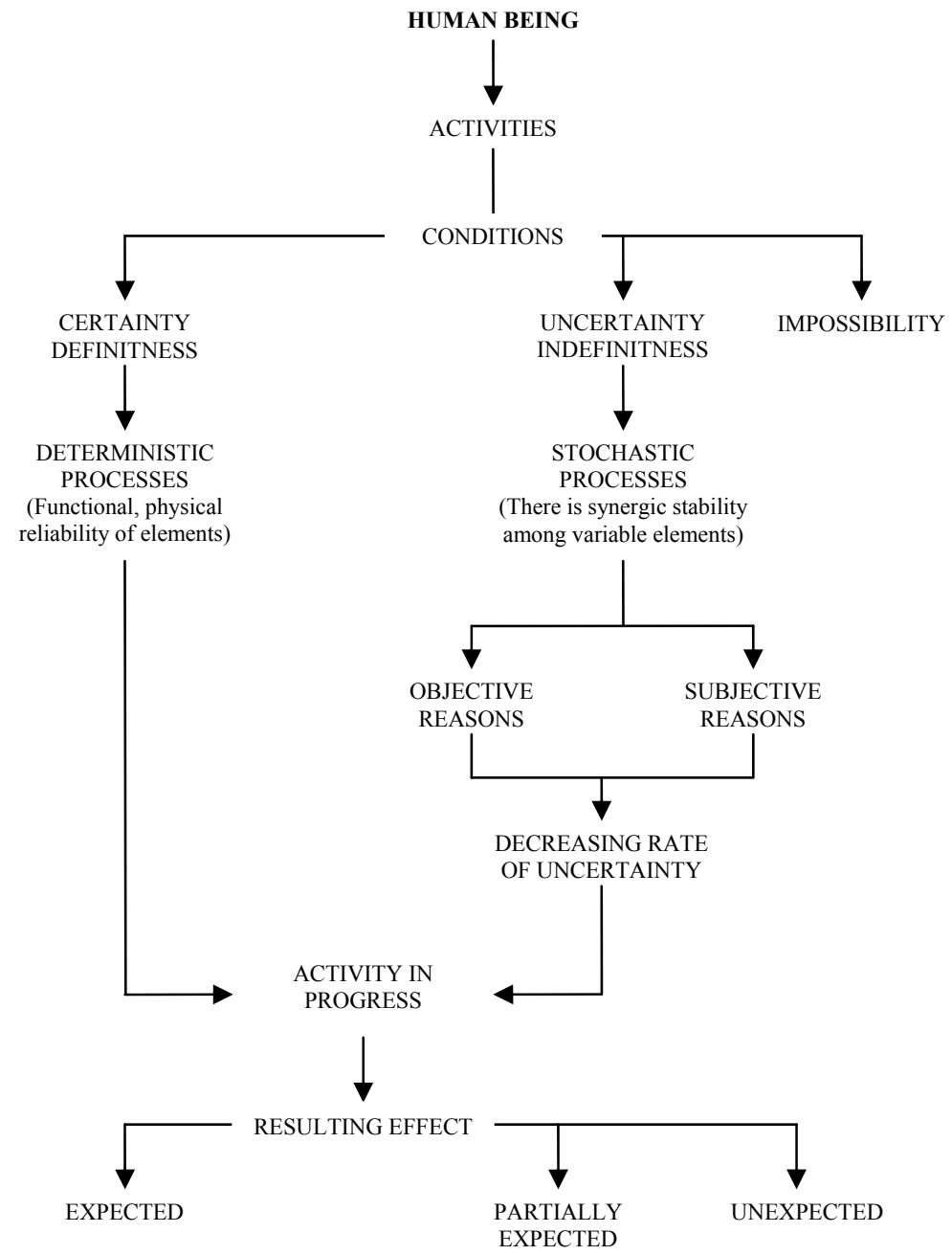

Figure 2: Schematic depiction of the progress of human activities. Source: Šmák [13].

\section{Systematic method of risk assessment in industrial processes}

The risks connected with the technical and technological processes can be a source of unplanned interruption of the manufacturing processes or can violate providing a service and can cause material losses, damage the environment and threaten the health and lives of people. A whole range of technical and 
technological processes can endanger not only the participating employees, but also inhabitants from the surroundings and in the case of a leakage of dangerous substances it can become a source of damage to nature, the environment and endanger the inhabitants for a long-time period, if not forever. Assessing the risks in the industrial processes and their decreasing them has a whole range of specifics whose recognition and acceptance is very important for improving the level of safety of the whole society and its continual progress.

There are lots of models and methods for assessing the risks; however, most of them use a special terminology and specify the same facts in a different way. The aim of this part is to suggest an algorithm for assessing the risks through structured diagrams.

The subject of research of the presented risk assessment model is particularly the area of technological processes in the industrial environment where hazardous substances are used. The created systematic procedure can create a supporting system for carrying out an analysis, especially in the SMEs. It can also be used for analysing the process of continuity control in the operational processes of the enterprise (Business Continuity Management) whose mission is to secure the operation of all important processes inside the organisation if any unexpected event occurs.

Implementing the currently utilised procedures ARAMIS and PRA requires good knowledge and experience. They are relatively demanding and are utilised especially for the SEVESO companies with selected hazardous substances. The need to create a transparent procedure with mutually complexly linked steps is inevitable. The systematic procedures serve the processors of the risk assessments of the technological processes with the presence of a hazardous substance for better orientation in the given area, as well as for approximation of the fulfilment of the individual phases and will make the selection of the methods and techniques for their implementation in the individual steps easier. Creating the logical sequence of the phases and steps, according to which the analyst should advance, is also emphasised. The phases of risk assessment can be depicted by a simplified model that shows the involvement of the analyst, the manager (decision-maker) and the working team in the whole process. The basic structure of the model can be seen in figure 3 .

\subsection{Preparation phase for risk assessment}

The preparation phase is the basis for realising further activities in the framework of the whole process of risk management; its extensiveness and quality realisation predetermine the resulting quality of the overall analysis. Its steps are depicted in the figure 4 and are described in the following text.

Risk assessment can be carried out based on the requirements of the law of the National Assembly of the Slovak Republic No. 261/2002 about the prevention of serious industrial accidents and the law of the National Assembly of the Slovak Republic No. 124/2006 about safety and health protection at work. Another objective can be fulfilling the requirements of the implemented or newly applied company risk management or acquiring the materials for the insurance 


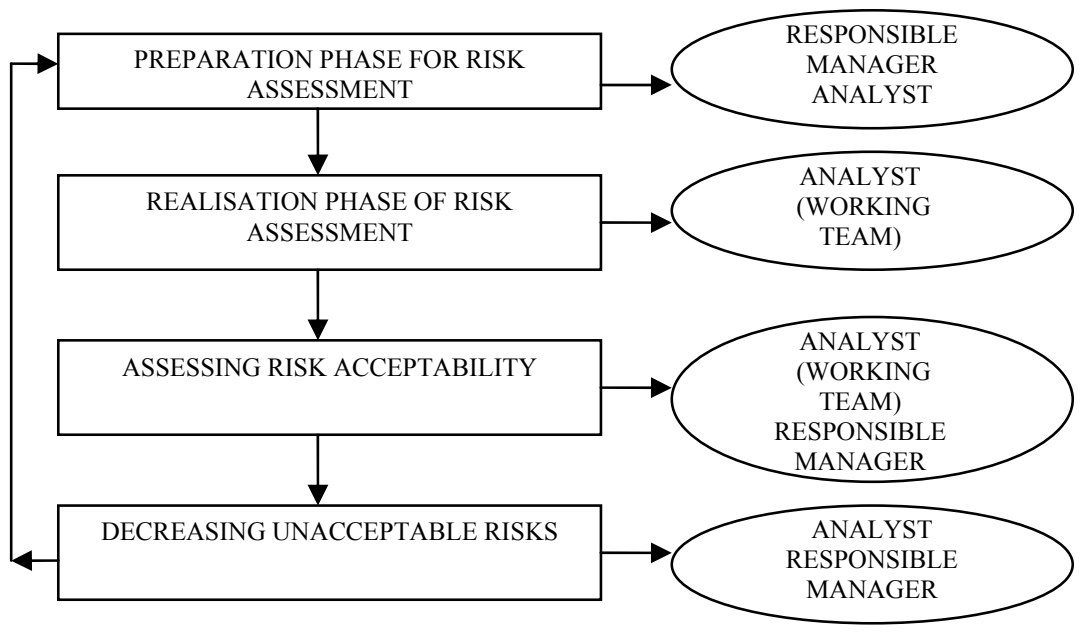

Figure 3: $\quad$ Basic structure of the risk assessment model.

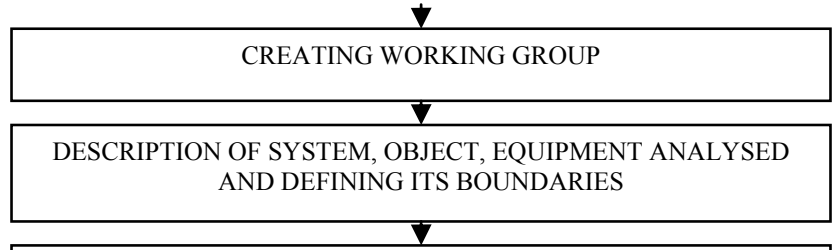

STATING LEVEL OF SERIOUISNESS OF RISK SOURCES AND SCENARIOS AND LEVELS OF ACCEPTABLE RISKS

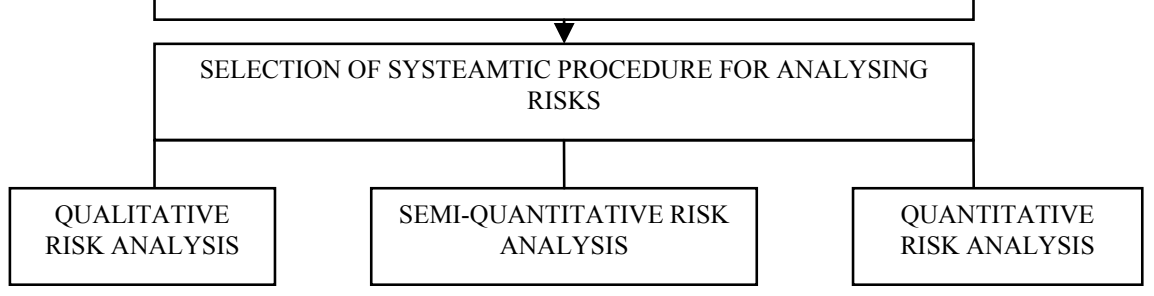

Figure 4: $\quad$ Sequence of preparation phase steps for risk assessment.

company. Part of the first step is to state the extent (depth) of the analysis (stating details of the analysis realised). It depends especially on the goal and purpose of the risk assessment. The further step is to create the working group that participates especially in the realisation phase of the risk assessment. The risk analyst is the coordinator here.

The other members are those employees who know the operation, technology or the assessed equipment in detail and the other ordinary employees who are necessary for the risk analysis. Furthermore the description of the analysed 
system, object, equipment and defining its boundaries is determined. It is carried out on the basis of information acquired about the object investigated, the company environment, description of the company and its activity. Stating criteria is an important part of the risk assessment preparation phase. Although the estimation of the risk is frequently technically possible and well determinable and can provide objective rates of the risk, its perception depends on the subjective characteristics of the manager - the decision-maker and the risk analyst. The selection of the systematic procedure or method for risk assessment is affected by the objective and extent of assessment and the accessibility and adequacy of the data that will be used. The risk analyst has to possess necessary knowledge for coping with the given area and to collaborate with people who realise the management decisions.

Information that passes from the preparation phase to the realisation phase is depicted in figure 5 .

The preparation phase serves especially for gathering information for further analysis. Its extent and duration depend on the complexity of the object assessed (equipment, system) and the rate of accessibility of the information required. Its correct completion is an important input for the realisation phase of the risk assessment.

\subsection{Realisation phase of risk assessment}

The realisation phase follows the preparation phase of the risk assessment. In this part the risk analyst and the working group are the most important agents (if any decision from the company side is made, the responsible manager is to be present).

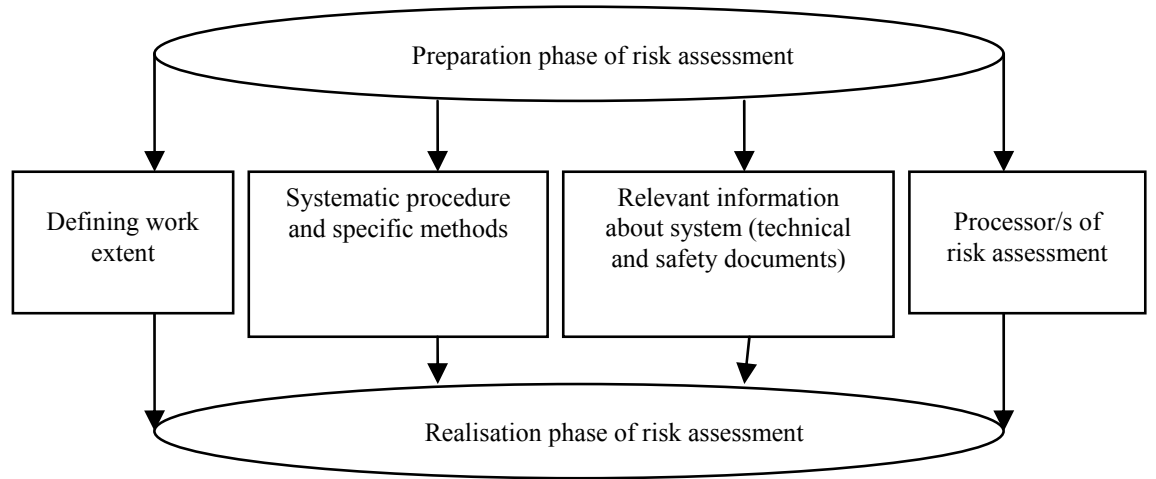

Figure 5: Information entering from the preparation to the realisation phase of risk assessment. 


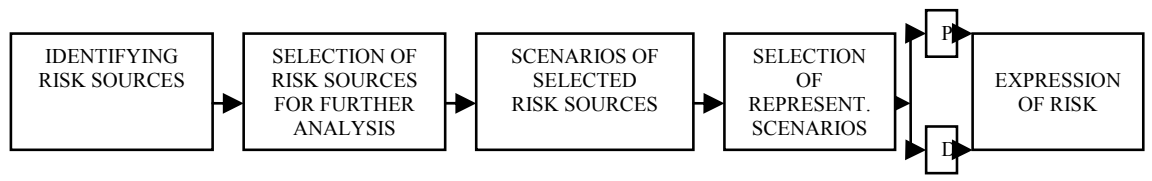

Figure 6: $\quad$ Steps of realisation phase for risk assessment.

Figure 6 depicts the individual steps that create the realisation part of the risk assessment. Their interpretation, as well as content, can differ in dependence on the sources and type of the environment investigated, as well as the systematic procedure used. The objective of identifying the risk sources is revealing their internal and external sources, which in a complex way affects the operational capability and the performance efficiency of the technological process. When selecting the sources of risk for further analysis, serious sources based on the in advance stated criteria are chosen and consequently are subject to a complex analysis. Creating scenarios is a step that serves for identifying and creating scenarios of selected risk sources from the initial event (cause) up to undesirable events (consequences and impacts). The goal of selecting scenarios is to choose such scenarios that will be further subject to qualitative, semi-quantitative or quantitative assessment and subsequently in the next step the results, impacts and probability or frequency of the undesirable phenomenon and their assessment will be stated. Based on the previous steps the extent of the risk will be determined and subsequently its acceptability will be assessed.

\section{Model of systematic method for risk assessment in industrial processes}

The model of the systematic method of risk assessment in industrial processes in figure 7 contains the sequence of steps of the preparation phase of risk assessment, the realisation phase of risk assessment, the phase of risk acceptability and decreasing the risks out of which the first two have been described in the previous text. Individual steps necessary for correctly realising and securing the complexity of the assessment in the whole process were explained and characterised in each phase. Mutual linkage, especially from the point of view of the input of the necessary data to further steps, is depicted in the individual steps.

The model was set up on the basis of analysing the already existing procedures (e.g. MOSAR, ARAMIS).

This model can be utilised for assessing the risks with the following goals:

- fulfilling the legal requirements (e.g. law of the National Assembly of the Slovak Republic No. 261/2002 about the prevention of serious industrial accidents, as amended),

- controlling the operating process continuity (identifying and analysing the risks in the microeconomic environment),

- risk assessment in the area of safety and health at work. 


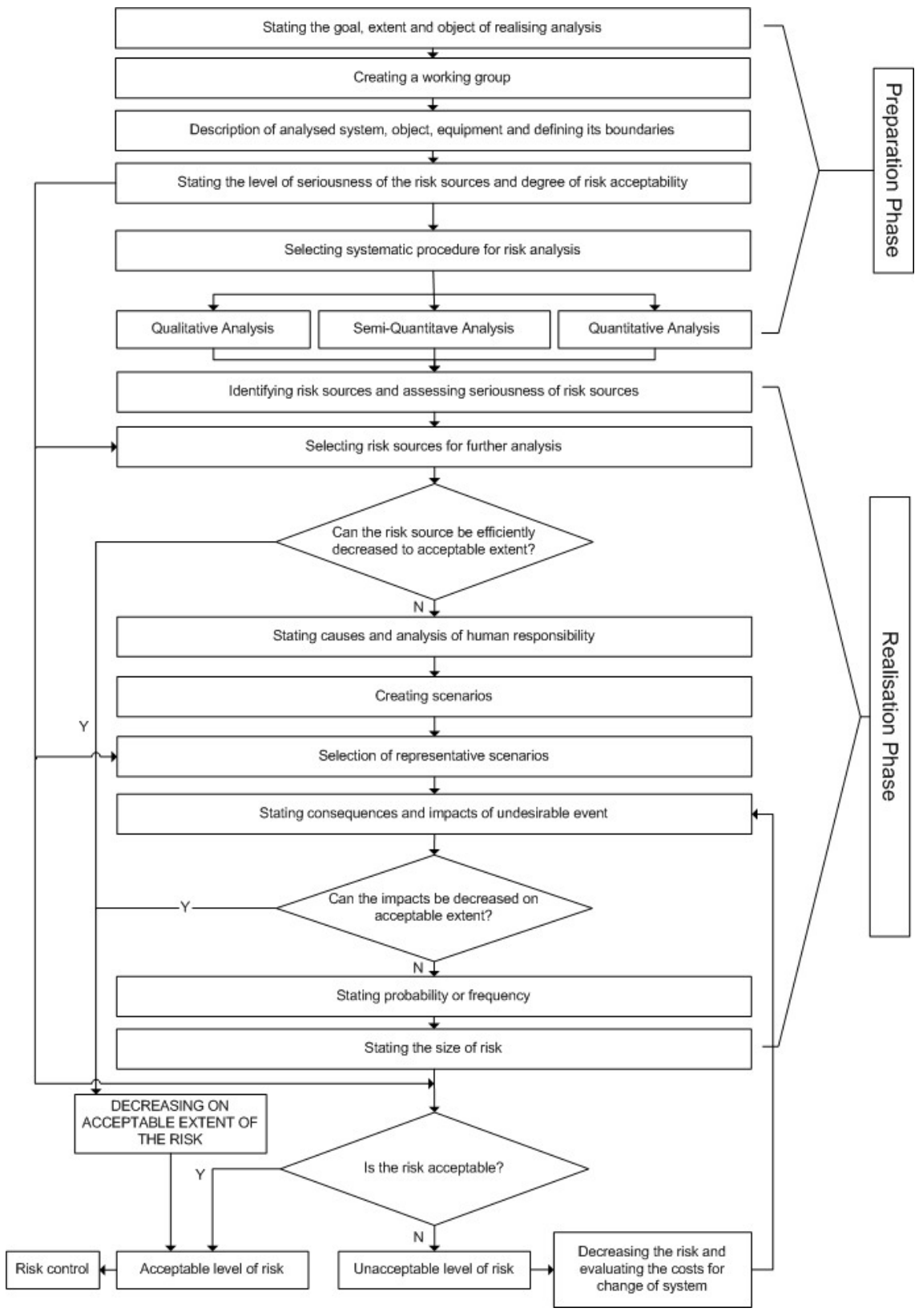

Figure 7: Model of systematic methods of risk assessment in industrial processes. 
The characteristic of the last phase of the model of risk assessment decreasing unacceptable risks - is not included in this article due to the extensiveness of this area.

\section{Conclusion}

The risk assessment of the technological processes in the industrial environment is an area that is actual both from the point of view of the scientific knowledge and social practice. Technological processes where hazardous substances are the potential threats for employees, the public, the environment and property should be given increased attention. In the time of increased demands on the safety of the technological processes (which are also part of the risk assessment), the idea of prevention becomes dominant. A systematic approach was presented that provides a sequence of phases for the risk assessment of the technological processes in the industrial environment and explains the content of fulfilling the individual steps, which is unambiguously a contribution for the processors of the risk assessments. The model created complies with the currently valid legal regulations in the area of prevention against industrial accidents and is in balance with the used procedures for practical risk assessment in Slovakia as well as the EU. One of the possible ways of dealing with new challenges in this field is also to support the exchange of the best experience and knowledge. For this reason, the University of Žilina, apart from its scientific and research activity, creates the communication space for discussion via the European project: Competency Based e-portal of Security and Safety Engineering, which seeks to create a network of educational, research and financial institutions operating in the security field in the EU.

\section{Acknowledgement}

Preparation of this paper has been supported by VEGA No. 1/0797/10, Project: Complex Risk Modeling Threaten Cities Security.

\section{References}

[1] Allen, D.: Risk management in Business. Cambridge: Cambridge University Press, 1995.

[2] Andersen, H., - Casal, J., - Dandrieux, A., - Debray, B., - De Dianous, - V., Duijm, N.-J., Delvosalle, - C., Fievez, C., - Goossens, L., - Gowland, R.-T., Hale, A.-J., Hourtolou, D., - Mazzarotta, B., - Pipart, A, - Planas, E., Prats, F., - Salvi, O., - Tixier: ARAMIS (Accidental Risk Assessment Methodology for Industries in the context of the SEVESO II Directive), Project under the 5th framework programme, 2008.

[3] Aven, T.: Foundations of Risk analysis. Norway: John Wiley \& Sons, 2005. ISBN 0- 471 - 49548 - 4. 
[4] Balog, K., - Bartlová, I.: Risk Assessment / Prevence technologických zařizení. Ostrava: Edice SPBI spektrum 30, 2007. ISBN 978-80-7385-0050 .

[5] Balog, K.- Bartlová, I.: Risk Assessment and Prevention in Industrial Processes / Analýza nebezpeči a prevence průmyslových havárii I. Ostrava: Edice SPBI spektrum 7, 2007.ISBN 80-86634- 10-8.

[6] Bernatík, A: Risk Assessment / Prevence závažných havárií. Ostrava: Technická univerzita Ostrava, 2006.

[7] CCPS: Guidelines for Chemical Process Quantitative Risk Analysis. New York: AICE, 2000. ISBN 0 - 8169-0720 - X.

[8] Kandráč, J. et al.: Methodology for risk companies / Metodická príručka pre zarad'ovanie rizikových podnikov s podprahovými množstvami vybraných nebezpečných látok a pre predbežný odhad rizika vodnikoch podliehajúcich režimu zákona o závažných haváriách. Bratislava: MŽP SR, 2001.

[9] Kopecký, Z.: Aspects of crisis legislative of Czech Republic in Business Continuity Plan structure, Krizový management - Crisis management, Fakulta špeciálného inžinierstva Žilinskej univerzity v Žilině, Žilina 2009, ISSN 1336-0019, č.1/2009, str. $61-65$

[10] Loveček, T., Kampová, K.: Application of quantitative methods in protection of strategic subjects, In: Varstvoslovje: Journal of criminal justice and security, Vol. 11, no. 4, s. 536-547, 2009, ISSN 1580-0253.

[11] Malder, G.: Deterministic and probabilistic approaches in risk analysis. [online]. [cit. 2010-06-14]. Dostupné na: http://mahbsrv.jrc.it/Proceedings/ Greece-Nov-1999/F2-VANMALDER-z.pdf

[12] Šimák, L.: Crisis Management / Krízový manažment vo verejnej správe, Žilina: FŠI ŽU, 2001, ISBN 80-88829-13-5.

[13] Šimák, L.: Risk Management / Manažment rizik - students handbook, Žilina: FŠI ŽU, 2006.

[14] The Institution of Engineering and Technology: Event Tree Analysis. In: Health and Safety Briefing No.26b, 2009.

[15] Vose, D.: Risk Analysis - A Quantitative Guide, third edition, John Wiley \& Sons Inc., 2008, ISBN 978-0-470-51284-5. 